\title{
Cloning of phenazine carboxylic acid genes of Fusarium fujikuroi antagonists bacteria
}

\author{
Maesomeh Anvari ${ }^{*}$ and Mohammad Reza Safari Motlagh ${ }^{2}$ \\ ${ }^{1}$ Department of Microbiology, Faculty of Sciences, Islamic Azad University, Rasht, Iran \\ ${ }^{2}$ Department of Plant Pathology, Faculty of Agriculture, Islamic Azad University, Rasht, Iran. \\ Accepted 28 January, 2009
}

\begin{abstract}
Bakanae disease caused by Fusarium fujikuroi is an important diseases on rice. Pseudomonas fluorescens produces the broad-spectrum antibiotic phenazine-carboxylic acid (PCA), which is active against a variety of fungal root pathogens. In this study two genes from seven gene locus of phenazine were cloned in Escherichia coli DH5a. The contaminated rice samples were collected from infected farms of Guilan. 238 bacteria were isolated from the rhizosphere. The antagonistic ability of 12 of which, was demonstrated with dual culture method. From the biochemical and culture results, 8 isolated were identified as $P$. fluorescens. The two genes from seven gene locus of phenazine were cloned into $E$. coli DH5a. We speculate that $P$. fluorescens that produce 2,4-diacetylphloroglucinol (Phl) play an important role in the natural suppressiveness of this soil to causal agent of collar and root rot of rice.
\end{abstract}

Key words: Fusarium fujikuroi, phenazine carboxylic acid, gene cloning, antagonist bacteria.

\section{INTRODUCTION}

There is increasing interest in applying microorganisms to control soil-borne plant pathogens. Inconsistent performance of the microorganisms, however, has hampered commercial application. Combining several modes of action against plant pathogens in one single organism by genetic modification can improve the efficacy of biological control agents (Van Loon, 1998). Bacterial secondary metabolites play critical roles in many aspects of bacterium-host interactions. Secondary metabolites that function as virulence factors play a central role in disease by altering host tissues (Kimura et al., 2001; Rahme et al., 1995). Other secondary metabolites produced by beneficial bacteria can function to prevent infection by pathogens by altering the environment and improving the bacterium's ability to compete with pathogens, by inhibiting the activity of pathogens, or by triggering host defenses (Bloemberg and Lugtenberg, 2001; Raaijmakers et al., 2002). The antibiotics phenazine-1carboxylic acid (PCA) and 2,4-diacetylphloroglucinol (Phl) are major determinants of biological control of soil-borne plant pathogens by various strains of fluorescent Pseudomonas spp. (Raaijmakers et al., 1997). The ability to produce phenazines is limited almost exclusively to

\footnotetext{
*Corresponding author. E-mail: anvari@iaurasht.ac.ir.
}

bacteria and has been reported in members of the genera Pseudomonas, Streptomyces, Nocardia, Sorangium, Brevibacterium, and Burkholderia (Turner and Messenger, 1986). Particularly among fluorescent Pseudomonas, the production of 2,4 diacetylphloroglucinol (DAPG), Plt (pyoluteorin), Prn (pyrrolnitrin) and different derivatives of phenazine has been described (Thomashow and Weller, 1996). Pseudomonas putida WCS358r was modified to produce the antifungal compound phenazine-1-carboxylic acid (PCA) (Thomashow et al., 1990). One possible approach to improve biological control may be the application of combinations of biocontrol agents (Duffy and Weller, 1995). By combining microorganisms, multiple antifungal traits can be combined and one may assume that at least one biocontrol mechanism will be functional under the conditions faced by the released biocontrol agents. Moreover, combinations of biocontrol strains are expected to result in a higher level of protection (Dunne et al., 1998), have reduced variability of biological control (Guetsky et al., 2001; Guetsky et al., 2002), and have potential to suppress multiple plant diseases (Jetiyanon and Kloepper, 2002). It has been demonstrated that natural suppressiveness of the Châteaurenard soil in France against Fusarium wilt is based on various mechanisms involving several microbial populations acting alone or together to limit the activity of the pathogen (Alabouvette, 
Table 1. Bacterial strains, plasmids and primers used in this study.

\begin{tabular}{|l|l|}
\hline Strain, plasmid or primer & Description or sequence \\
\hline Strains & \\
Pseudomonas fluorescens 2-79 & Phz_Rifr, produces PCA \\
Pseudomonas fluorescens F15 & Phz, produces PCA \\
Pseudomonas fluorescens F15 & Phz, produces PCA \\
Escherichia coli DH5a & F_traD36 proA_proB_lacla lacZ \\
Plasmid & \\
pUC - 18 & ColE1 bla \\
Primers & \\
PHZ - UP & TAAGGATCCGGTAGTTCCAAGCCCCAGAAAC \\
PHZ - LOW & CACATTTGATCTAGATGGGTCACGGCTATTCAG \\
\hline
\end{tabular}

1998).Our objective is to clone entire locous of PCA from antagonist bacteria of Fusarium fujikuroi isolated from Guilan rice field to Escherichia coli DH5a.

\section{MATERIALS AND METHODS}

\section{Isolation of $F$. fujikuroi}

Rice bakanae disease was collected from infected farming in different areas as Rasht, Lahijan, Foman, Anzaly, Talesh and Astara in the Guilan province, Iran. For isolation of $F$. fujikuroi, small pieces of infected root with bakanae disease, was washed and surface sterilized with $5 \%$ sodium hypochlorite for $10 \mathrm{~min}$. The infected tissues were cultured on acidified potato dextrose agar (PDA).

The plates were incubated at room temperature $26^{\circ} \mathrm{C}$ for a week. The growing colonies of fungi were transferred to new plates for purification and identification.

\section{Isolation of antagonistic bacteria isolates and identification}

Antagonistic bacteria which colonized rice rhizosphere, one gram of exercised roots were shaked at $100 \mathrm{rpm}$ in $100 \mathrm{~mL}$ of sterile distilled water for $25 \mathrm{~min}$. Fluorescent pseudomonads under UV light $(I=356 \mathrm{~nm})$ were isolated on King's medium $B(K B)$. According to the methodology of Schaad et al. (2001), antagonistics isolates of bacteria were identified by biochemical, physiological, biological tests and PCR.

\section{Screening for antifungal activity}

Screening for antifungal activity was performed on PDA medium. Under this condition, fungal growth inhibition could be due to production of antifungal metabolites. Pathogen used was $F$. fujikuroi. An agar plug (5 mm diameter) taken from an actively growing fungal culture was placed on the surface of the PDA plate. Simultaneously, $P$. fluorescens strains were streaked $3 \mathrm{~cm}$ away from the agar plug at sides towards the edge of Petri plates. Plate inoculated with fungal agar plugs alone was used as control. The plates were incubated at $27^{\circ} \mathrm{C}$ until fungal mycelia completely covered the agar surface in control plate. Strains that inhibited mycelial growth of fungus were tested. Ability of antagonistic bacteria to production of volatile antibiotic, secretion of extracellular and production of diffusible antibiotic were tested according to Montealegro et al. (2003).

Results are expressed as means of inhibition (\%) of the growth of $F$. fujikuroi in the presence and absence of any bacterial isolate. Percent inhibition was calculated using the fallowing formula (Montealegro et al., 2003).

Inhibition (\%) $=[(1-$ (fungal growth $/$ Control growth) $] \times 100$.

\section{Bacterial strains, plasmids and primers}

The bacterial strains plasmids and primers used in this study are described in Table 1. Pseudomonas strains were grown at $28^{\circ} \mathrm{C}$ in king's B, 23 YT broth (Sambrook et al., 1989), while E. coli strains were grown in Luria-Bertani or $23 \mathrm{YT}$ broth at 28 or $37^{\circ} \mathrm{C}$.

\section{DNA manipulations}

Standard methods were used for DNA purification, restriction enzyme digestion, agarose gel electrophoresis, and ligation (Ausubel et al., 1995). Genomic DNA was isolated and purified by a cetyltrimethylammonium bromide (CTAB) miniprep procedure. A 6.4-kb DNA probe containing the entire phz locus from $P$. fluorescens F15 was generated by PCR performed with oligonucleotide primers phz-up and phz-low (Table 1). The amplification was carried out by using a $50 \mu \mathrm{l}$ reaction mixture containing $1 \mathrm{x}$ eLONGase buffer (Life Technologies, Inc., Rockville, Md.), 2 mM $\mathrm{MgSO}_{4}, 3.0 \%$ dimethyl sulfoxide, $200 \mu \mathrm{M}$ (each) dGTP, dATP, dTTP, and dCTP, $10 \mathrm{pmol}$ of each primer, $0.7 \mu \mathrm{l}$ of eLONGase enzyme mixture (cinagene, Inc.), and $20 \mathrm{ng}$ of purified genomic DNA from isolated strains. All amplifications were performed with a PTC- 200 thermal cycler. Amplification was performed in a thermal cycler programmed

The reaction conditions are: a initial denaturation of $94^{\circ} \mathrm{C}$ for 2 min followed by 37 cycles of $94^{\circ} \mathrm{C}$ for $1 \mathrm{~min}, 64^{\circ} \mathrm{C}$ for $1 \mathrm{~min}$, and $72^{\circ} \mathrm{C}$ for $1 \mathrm{~min}$. A final extension step of $72^{\circ} \mathrm{C}$ for 10 min finishes the reaction. Amplified DNA fragments were examined by horizantal electrophoresis in 1.5\% agarose gel in TBE buffer $90 \mathrm{mM}$ Trisborate, $2 \mathrm{mM}$ EDTA [pH 8.3]), with $8 \mu \mathrm{L}$ aliquots of PCR products. Gels were stained with ethidium bromide and were photographed under UV light (312 nm).

\section{Transformant screening and protein expression}

Recombinant cells were identified by plating on to agar medium containing ampicillin, X-Gal and IPTG.

For protein expression E. coli $\mathrm{DH} 5 a$ harboring pUC18 was grown in LB broth to an optical density at $600 \mathrm{~nm}$ and induced with 0.5 $\mathrm{mM}$ Isopropylb- D-thiogalactopyranoside (IPTG). Cells were harvested $3 \mathrm{~h}$ later and total cellular protein was analyzed by electrophoresis in an SDS-10\% polyacrylamide gel. 
Table 2. Effect of antibiosis of Pseudomonas fluorescens isolates on radial growth of Fusarium fujikuroi in vitro.

\begin{tabular}{|c|c|c|c|c|c|c|c|c|c|c|c|}
\hline \multirow[b]{2}{*}{ Antibiosis (Inhibition (\%) } & \multicolumn{11}{|c|}{ Pseudomonas fluorescens isolates } \\
\hline & $\mathbf{F 1}$ & F6 & F12 & F15 & F16 & F18 & F21 & F25 & $\begin{array}{r}2-79 \\
\text { RN }\end{array}$ & $\begin{array}{c}\text { F15 } \\
\text { (pUC-PCA) }\end{array}$ & $\begin{array}{c}\text { F16 } \\
\text { (pUC-PCA) }\end{array}$ \\
\hline Daul culture & $40 d$ & $41 d$ & $48 c$ & $55 b$ & $50 c$ & $49 b$ & $50 c$ & $48 c$ & $59 a$ & $58 \mathrm{a}$ & $58.5 a$ \\
\hline Volatile antibiotics simultaneously & $51 d$ & $52 d$ & $60 c$ & $65 b$ & $61 c$ & $59 c$ & $61 c$ & $59 c$ & $69 a$ & $68 a$ & $68 a$ \\
\hline Volatile antibiotics $72 \mathrm{~h}$ & $54 d$ & $54 d$ & $63 d$ & $69 b$ & $63 c$ & $60 c$ & $63 c$ & $62 c$ & $72 a$ & $70.5 a$ & $71 a$ \\
\hline Antibiotics & $58 d$ & $60 d$ & $68 c$ & $77 b$ & $70 c$ & $68 c$ & $67 c$ & $69 c$ & $80 a$ & $79 a$ & $79 a$ \\
\hline Secration of extracellular $(25 \% \mathrm{v} / \mathrm{v})$ & $62 d$ & $63 d$ & $73 c$ & $80 \mathrm{~b}$ & $73 c$ & $74 \mathrm{c}$ & $74 \mathrm{C}$ & $75 c$ & $83 a$ & $82 a$ & $82.5 a$ \\
\hline
\end{tabular}

Means followed by a common letter in a row are not significantly different according to LSD (T) test at $P<0.01$.

\section{RESULTS}

\section{Isolation of antagonistic bacteria}

Two hundred thirty eight bacterial isolates were initially collected from the rhizoplane and rhizosphere of rice sheath blight disease in different farming of area of the Guilan province-Iran. Among them, thirteen isolates were found to inhibit growth of $F$. fujikuroi in vitro. Eight isolates; F1, F6, F12, F15, F16, F18, F21 and F25 were identified as Pseudomonas fluorescens biovar 3 according to the methodology of Schaad et al. (2001).

\section{Identification of $\boldsymbol{P}$. fluorescens isolates by direct PCR}

All isolates of Pseudomonas fluorescens were identified by specific primers PCA1 and PCA2. On agarose gel electrophoresis $2 \%$, isolates were produced a band 1110 bp (expected size). The bands of isolates were similarly with isolate standard of 2-79 RN (Figure 1).

\section{Mycelium inhibition assays}

Two hundred thirty eight bacterial isolates were initially collected from the rhizoplane and rhizosphere of rice bakanae disease in different farming of area of the Guilan province-Iran. Among 268 isolates, two bacterial isolates (F15 and F16) were selected to the inhibit mycelium growth of $F$. fujikuroi greater than others (Table 2).

\section{Specificity of PCA primers}

Primers phz-up and phz-low amplified the entire locus of $P$. fluorescens strain 2-79 RN (Figure 1). The specificity of PCA primers was reported in earlier study (Dimetri et al., 2001).

\section{Cloning detection}

The fragment (1110 bp) was cloned into pUC18, and positive clones, were identified by standard methods

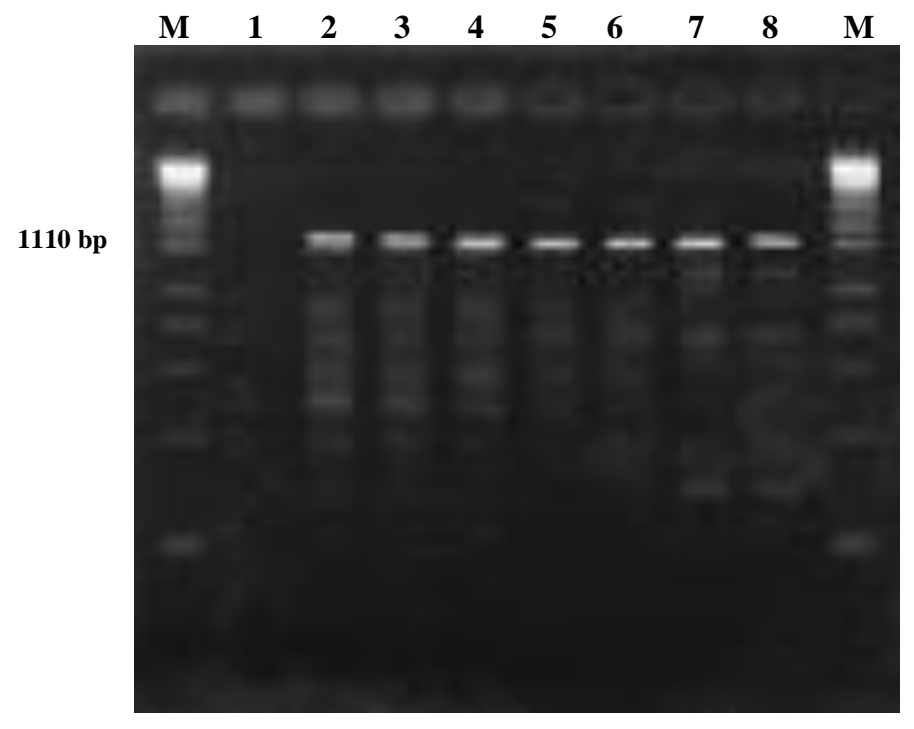

Figure 1. Agarose gel electrophoresis of the PCR products amplified from genomic DNA of isolated Pseudomonas strains with PCA1 and PCA2 primers phz-up and phz-low. Lane M, DNA 1-kb ladder marker $(0.2 \mathrm{ng})$. Lane 1 , negative control; Lanes 2 to 6 antagonists bacteria; Lane 7 positive control ( $P$. fluorescens 2-79 $\mathrm{RN})$.

(Ausubel et al., 1995). The antibiotic PCA is major determinant of biological control of soil-borne plant pathogens by strains of fluorescent Pseudomonas spp. (Thomashow and Weller, 1996).

\section{DISCUSION}

In several bioassays, strain F15 (pUC - PCA) and F16 ( $\mathrm{pUC}$ - PCA) were able to suppress bakanae disease of rice by effectively of antifungal activity. In this study, we described variety of strains that inhibit mycellial growth of $F$. fujikuroi and screened a collection of phenazineproducing strains of $P$. fluorescens. The production of PCA increased antifungal activity of WCS358r and DAPG production resulted in an enhanced ability to inhibit growth of both fungi and bacteria. PCR and southern hybridization analysis were performed to determine the 
presence of genes involved in the biosynthesis of phenazine-derivatives described in $P$. fluorescens $2-79$ and Pseudomonas aureofaciens 30 - 84. Loci phzC, phzD (Mavrodi et al., 1998). For the presence of PCAgenes by direct PCR. Also we successfully cloned the entire locus of phenazine in $E$. coli $\mathrm{DH} 5 a$ with specific primers. Results indicated that phenazine biosynthesis is highly conserved among phenazine-producing strains of $P$. fluorescens. Cloning of different fragment of the locus can described the structure and function of the biosynthetic gene clusters from the isolated strains. Characterization of phenazine regulation by strains of $P$. fluorescens $\mathrm{F} 15$ and $\mathrm{F} 16$ has revealed many complexities in the activation of phenazine production, but prior to this study, genetic screens had not identified any negative regulators. We speculate that fluorescent Pseudomonas spp. that produce Phl play an important role in the natural suppressiveness of bakanae disease of rice. Because phenazine production by strain 2-79 RN contributes to its capacity in biological control, we tested the ability of F15 and F16 to inhibit $F$. fujikuroi. In in vitro plate assays, strain $\mathrm{F} 15$ and $\mathrm{F} 16$ were better at inhibiting mycelial growth of the fungus than wild type strain 2-79 RN (Table 2). The environmental fitness of genetically modified microorganisms might be affected by the modification (De Leij et al., 1998). Future studies will determine the mechanism of PCA regulation of phenazine production and evaluate the long-term effect of the PCA mutation on bacterial colonization, persistence, and bakanae disease suppression on rice.

\section{REFERENCES}

Alabouvette C, Schippers B, Lemanceau P, Bakker PAHM (1998). Biological control of fusarium wilts. Pages $15-36$ in: Plant- Microbe Interactions and Biological Control. G. J. Boland and L. D. Kuykendall, eds. Marcel Dekker, New York.

Ausubel, FM, Brent R, Kingstons E, Moore, DD, Seidman JS, Smith JA, Struhl K (ed.). (1995). Short protocols in molecular biology. John Wiley \& Sons, Inc., New York, N.Y.

Bloemberg GV, Lugtenberg BJ (2001). Molecular basis of plant growth promotion and biocontrol by rhizobacteria. Curr. Opin. Plant Biol. 44:343-350.

Leij Faam DE, Thomas CE, Bailey MJ, Whipps JM, Lynch JM (1998). Effect of insertion site and metabolic load on the environmental fitness of a genetically-modified Pseudomonas fluorescens isolate. Appl. Environ. Microbiol. 64: 2634-2638.

Dimetri V, Mavrodi V, Robert F, Bonsall M, Shannon M, Delaney M, Marilyn J, Soule M, Phillips G, Tomassshow LS (2001). Functional Analysis of Genes for Biosynthesis of Pyocyanin and Phenazine-1Carboxamide from Pseudomonas aeruginosa PAO1. J. Bacteri. 6454-6465.
Duffy, BK, Weller DM (1995). Use of Gaeumannomyces graminis var. graminis alone and in combination with fluorescent Pseudomonas spp. to suppress take-all of wheat. Plant Dis. 79:907-911.

Dunne C, Moenne-Loccoz Y, Mccarthy J, Higgins P, Powell J, Dowling DN, Gara OF (1998). Combining proteolytic and phloroglucinolproducing bacteria for improved biocontrol of Pythium mediated damping-off of sugar beet. Plant Pathol. 47:299-307.

Guetsky R, Shtienberg D, Elad Y, Dinoor A (2001). Combining biocontrol agents to reduce the variability of biological control. Phytopathology, 91:621-627.

Guetsky R, Shtienberg D, Elad Y, Fischer E, Dinoor A (2002). Improving biological control by combining biocontrol agents each with several mechanisms of disease suppression. Phytopathology 92:976-985.

Jetiyanon K, Kloepper JW (2002) Mixtures of plant growth promoting rhizobacteria for induction of resistance against multiple plant diseases. Biol. Control 24:285-291.

Kimura M, Anzai H, Yamaguchi I (2001). Microbial toxins in plantpathogen interactions: biosynthesis, resistance mechanisms, and significance. J. Gen. Appl. Microbiol. 474:149-160.

Mavrodi DV, Ksenzenko VN, Bonsall RF, Cook, RJ, Boronin AM, Thomashow LS (1998). A seven-gene locus for synthesis of phenazine-1-carboxylic acid by Pseudomonas fluorescens 2-79. J. Bacteriol 180: 2541-2548.

Montealegro JR, Reyes R, Perez R, Herrera, LM, Silva, P, Besoain X (2003). Selection of bioantagonistic bacteria to be used in biological control of Rhizoctonia solani in tomato. J. Biotechnol. 6: 115-127.

Raaijmakers JM, Weller DM, Thomashow LS (1997). Frequency of antibiotic-producing Pseudomonas spp. in natural ecosystems. Appl Environ. Microbiol. 63:881-887.

Raaijmakers JM, Vlami M, De Souza JT (2002). Antibiotic production by bacterial biocontrol agents. Antonie Leeuwenhoek 81: (28).537-547.

Rahme, E LGEJ, Stevens SF, Wolfort J, Shao RG, Tompkins FM, Ausubel FM. (1995). Common virulence factors for bacterial pathogenicity in plants and animals. Science 268:1899-1902.

Sambrook J, Fritsch EF, Maniatis T (1989). Molecular cloning: a laboratory manual, 2nd ed. Cold Spring Harbor Laboratory Press, Cold Spring Harbor, N.Y.

Schaad NW, Jones JB, Chun W (2001). Laboratory Guide for Identification of Plant Pathogenic Bacteria. Thrid eds. APS. St. Paul. Minnesota, USA. p. 373.

Thomashow LS, Weller, DM (1996). Current concepts in the use of introduced bacteria for biological disease control: mechanisms and antifungal metabolites, pp. 187-236. In G. Stacey and N. T. Keen (ed.), Plant-microbe interactions, Vol. 1. Chapman \& Hall, Ltd., London, United Kingdom.

Thomashow LS, Weller DM, Bonsall RF, Pierson LS (1990). Production of the antibiotic phenazine-1-carboxylic acid by fluorescent Pseudomonas species in the rhizosphere of wheat. Appl. Environ. Microbiol. 56: 908-912.

Turner JM, Messenger AJ (1986). Occurrence, biochemistry and physiology of phenazine pigment production. Adv. Microbiol. Physiol. 27:211-275.

Van Loon LC (1998). Biotechnology as a means to improve biological control of plant diseases. Med. Fac. Landbouww. Univ. Gent. 63: (/4) 1657-1666. 